\title{
A Hierarchical Approach of Hybrid Image Classification for Land use and Land cover Mapping
}

\author{
Vahid Rahdari ${ }^{\mathrm{A}}$, Alireza Soffianian ${ }^{\mathrm{A}}$, Saeid Pourmanafi ${ }^{\mathrm{A}}$, \\ Razieh Mosadeghi ${ }^{\mathrm{B}}$,Hamid Ghaiumi Mohammadi ${ }^{\mathrm{C}}$
}

Received: August 22, 2017 | Revised: October 6, 2017 | Accepted: November 27, 2017

DOI: $10.5937 / 22-16620$

\begin{abstract}
Remote sensing data analysis can provide thematic maps describing land-use and land-cover (LULC) in a short period. Using proper image classification method in an area, is important to overcome the possible limitations of satellite imageries for producing land-use and land-cover maps. In the present study, a hierarchical hybrid image classification method was used to produce LULC maps using Landsat Thematic mapper TM for the year of 1998 and operational land imager OLI for the year of 2016. Images were classified using the proposed hybrid image classification method, vegetation cover crown percentage map from normalized difference vegetation index, Fisher supervised classification and object-based image classification methods. Accuracy assessment results showed that the hybrid classification method produced maps with total accuracy up to 84 percent with kappa statistic value 0.81 . Results of this study showed that the proposed classification method worked better with OLI sensor than with TM. Although OLI has a higher radiometric resolution than TM, the produced LULC map using TM is almost accurate like OLI, which is because of LULC definitions and image classification methods used.
\end{abstract}

Keywords: Error matrix, Hierarchical classification, Iran, land use/cover, Plasjan sub-basin

\section{Introduction}

Satellite data are often used to prepare land-use and land-cover maps. (Chrysoulakis et al., 2010; Lakshmi et al., 2015). Selection of proper land-use classification method is crucial in many inventories especially in watershed's uplands, which are usually water sources for wetlands (Anderson, 1976; Purkis et al., 2006; Mie et al., 2015; Tian et al., 2015). When satellite images data are used to produce LULC map, it is often very difficult to identify spectrally unique land-use/cover classes because of similar spectral responses arising from different features (Roy et al., 2014; Knudbya et al., 2014; Es- toque \& Murayama, 2015; Lakshmi et al., 2015). Several methods can be employed to produce LULC by employing remote sensing data (Purkis \& Klemas, 2011; Lakshmi et al., 2015; Al-doski et al., 2013). However, it should be noted that in case land surface objects have a similar reflectance or a small area, most of them could not provide high accurate maps (Gao \& $\mathrm{Xu}, 2016$ ). Using low radiometric resolution imageries, land classification can be a serious challenge because of spectral mixing of different surface elements and landscape complexity (Julien et al., 2011; Stenzel et al., 2016).

\footnotetext{
A Natural Resource Faculty, University of Zabol, Iran, Vahid_rahdary@yahoo.com; soffianian@cc.iut.ac.ir; Spmanafi@yahoo.com

B Griffith Centre for Coastal Management, Griffith University, QLD, Australia, R.mosadeghi@griffith.edu.au

c Soil \& Geomorphology in Iranian Soil and Water Research Institute, Isfahan, Iran, hghaiumi@gmail.com

* Corresponding author: Alireza Soffianian, e-mail: soffianian@cc.iut.ac.ir
} 
In such cases, application of hybrid classification approach in hierarchical way will produce better land-use/land-cover maps (Lakshmi et al., 2015). In this method, land-use/land-cover maps are produced by combining different methods like unsupervised, supervised, object-based methods and different indices produced from satellite images (Anderson, 1976; Homer et al., 2004; Di Gregorio, 2005; Disperati et al., 2015; Misra \& Balaji, 2015; Lakshmi et al., 2015).

Several studies compared the accuracies obtained by different image classification methods and ap- plied imageries with different radiometric resolutionsfor producing accurate LULC maps (Benfield et al., 2007; Alves et al, 2012; Vieira et al., 2012; Al-doski et al., 2013; Knudbya et al., 2014; Estoque \& Murayama, 2015; Mei et al., 2015; Disperati et al., 2015; Poursanidis et al., 2015; Mirsa \& Balaji, 2015; Knudby et al., 2015 ).

The objective of this study is to develop a hybrid classification method to prepare accurate land-use/ cover maps even when imageries with lower radiometric resolutions are used.

\section{Methods and data}

\section{The study area}

The study area was Pelasjan sub-basin including the western part of the Gavkhooni watershed located in central Iran and covering approximately 412,999 hectares. The Zayandehrood is the major river in Gavkhooni watershed to which Pelasjan sub-basin gives the highest portion of water. The Gavkhooni wetland is located in the eastern part of Gavkhooni watershed and is the terminal basin of the Zayandehrood River. Pelasjan sub-basin average temperature is $8-13 \mathrm{C}^{\circ}$ with 400-1250 mm precipitation. Agriculture activities and animal husbandry are the main activities of people living in these areas. Figure 1 shows the location of the Zayanderood River Basin and Pelasjan sub-basin in the western part of the Gavkhooni wetland in Iran.

\section{Dataset}

The Operational Land Imager (OLI) and Thematic Mapper (TM) sensors were launched with Landsat satellites and are useful in natural resources studies. OLI sensor measures in the visible, near infrared, and short wave infrared portions of the spectrum in 11 bands. TM sensors with 7 bands are in visible wavelengths and in infrared. The temporal resolution of both TM and OLI are 16 days. Considering the fact that the study area was located between two Landsat paths, 164 and 165, two images were downloaded from the USGS website. Because thehighest vegetation cover was in June and August, satellite images were downloaded for susceptive months. Table 1 shows satellite data selected for this study.

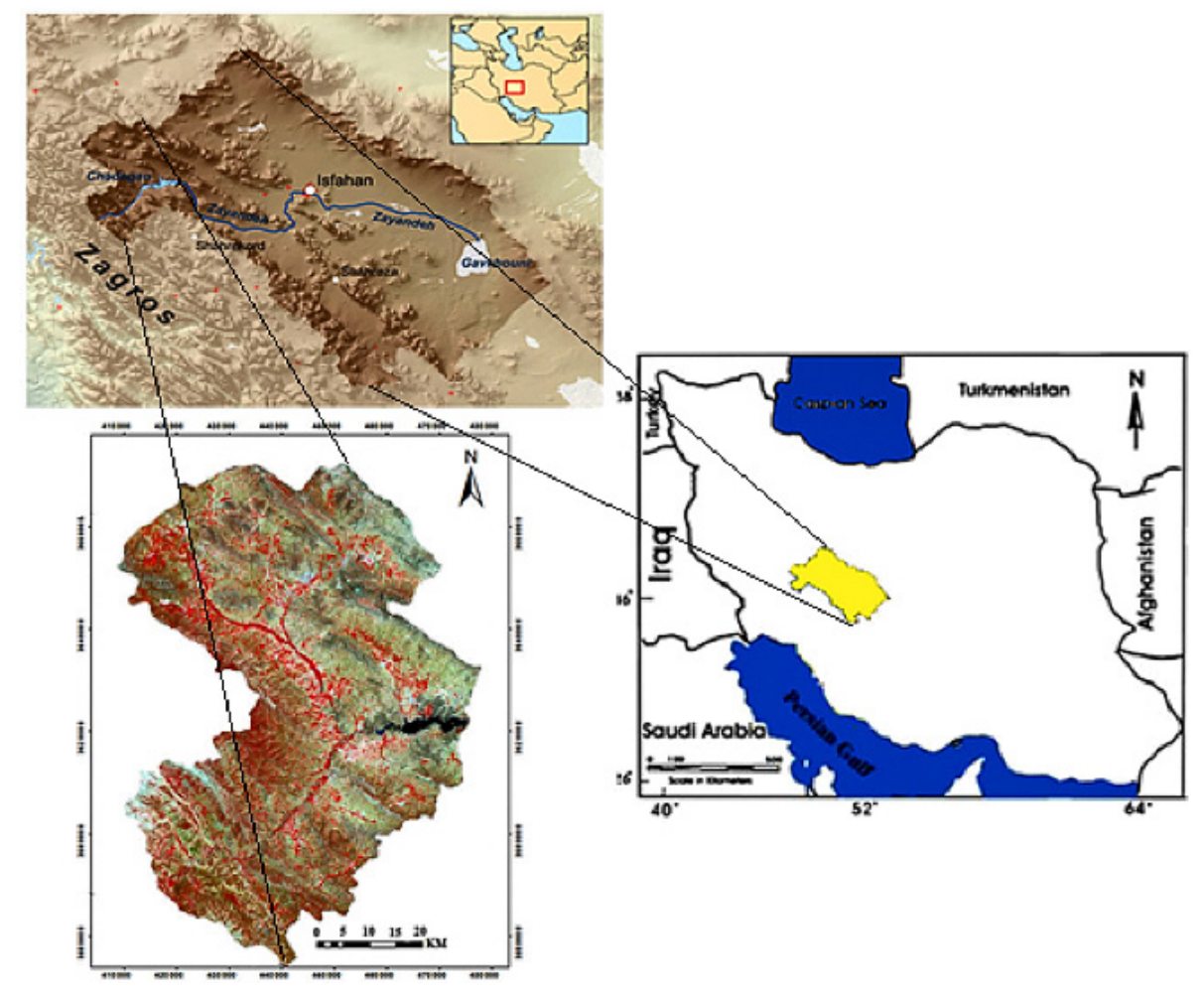

Figure 1. Pelasjan sub-basin located in the western part of Gavkhooni wetland 
Table1. Satellite sensor specification

\begin{tabular}{|c|c|c|c|c|}
\hline Date & Satellite & Sensor & Sensor ID & Pixel size \\
\hline 13-AUG-1998 & Landsat & TM & Path/row 165/37 & 30 \\
\hline 06-AUG-1998 & Landsat & TM & Path/row 164/37 & 30 \\
\hline 10-JUN-1998 & Landsat & TM & Path/row 165/37 & 30 \\
\hline 03-JUN-1998 & Landsat & TM & Path/row 164/37 & 30 \\
\hline 03-Jan-1998 & Landsat & TM & Path/row 164/37 & 30 \\
\hline 09-JUN-15 & Landsat & OLI & Path/row 165/37 & 30 \\
\hline 02-JUN-15 & Landsat & OLI & Path/row 164/37 & 30 \\
\hline 12-AUG-15 & Landsat & OLI & Path/row 165/37 & 30 \\
\hline 5-AUG-15 & Landsat & OLI & Path/row 165/37 & 30 \\
\hline
\end{tabular}

In addition, aerial images, digital elevation model 1:25/ooo topographic maps were used to best understand the study area's situation.

\section{Field studies}

Field studies were conducted to collect training areas for each LULC class to be used in the image classification. Positions of the lands under agricultural areas were determined with GPS. To check the status of the vegetation cover crown percentage (VCCP), 270 plots with 7.3 meters were measured.

In this study, samples from each LULC were collected by paying attention to imageries spatial resolution (30m); and they were collected in a homogenous area of LULC. In this order, we take samples in homogenous areas, which at least are more than 30-metersdistant from margins. Therefore, by avoiding marginal land-use/land-cover reflectance, we achieve almost pure reflectance samples for each LULC.

Because there were not enough data for $1998 \mathrm{im}$ age, by using topographic maps and aerials and by comparing TM and OLI image false color composites (FCC), NDVI images values in TM and OLI and field studies, VCCP in each recorded plot was predicted.

\section{LULC classification}

Based on the available data and field studies, 7 LULC classes were defined for the study area (Table 2).

\section{Satellite image Pre-processing}

Earth atmosphere is a mixed of gases, liquid and solid particles, most of these are optically active causing absorption, diffusion and scattering. Signals which measured at the satellite is the emergent radiation from the earth surface atmosphere system in the senor observation direction. The radiance measured at sensor is known as Top of Atmosphere (TOA) radiance. Atmospheric corrections aim to convert the TOA radiance of the objects into the near earth reflectance (Lakshmi et al., 2015). Atmospheric correction was done using Fast Line-of-sight Atmospheric Analysis of Spectral Hypercubus (FLAASH) algorithm. FLAASH was developed to provide accurate, physicsbased derivation of atmospheric properties in Envi 5.1. FLAASH includes correction for the adjacency effect, cirrus and opaque cloud classification and adjustable spectral polishing for artifact suppression (Jia et al, 2014; Lakshmi et al., 2015).

\section{Satellite image processing - Hierarchical image classification}

First, for image processing, the conceptual model of the three-level earth's surface matrix that was shown in Figure 2 was applied on both TM and OLI data.

Table 2. LULC classification (Feranec, et al., 2007; Feranec, et al., 2010)

\begin{tabular}{|l|l|}
\hline Short description & Class \\
\hline $\begin{array}{l}\text { Agricultural arewhich mainly are drainage with other than } \\
\text { rain water }\end{array}$ & Drainage agriculture \\
\hline Agriculture areas that irrigate only with rain water & Rain-fed agriculture \\
\hline Natural vegetation upper than $50 \%$ & Dense range land \\
\hline Vegetation cover crown less than $50 \%$ & Sparse range land \\
\hline Trees with rangelands & Forest \\
\hline Housing developments & Residential areas \\
\hline water bodies including; dam, natural and manmade lakes & Water bodies \\
\hline
\end{tabular}




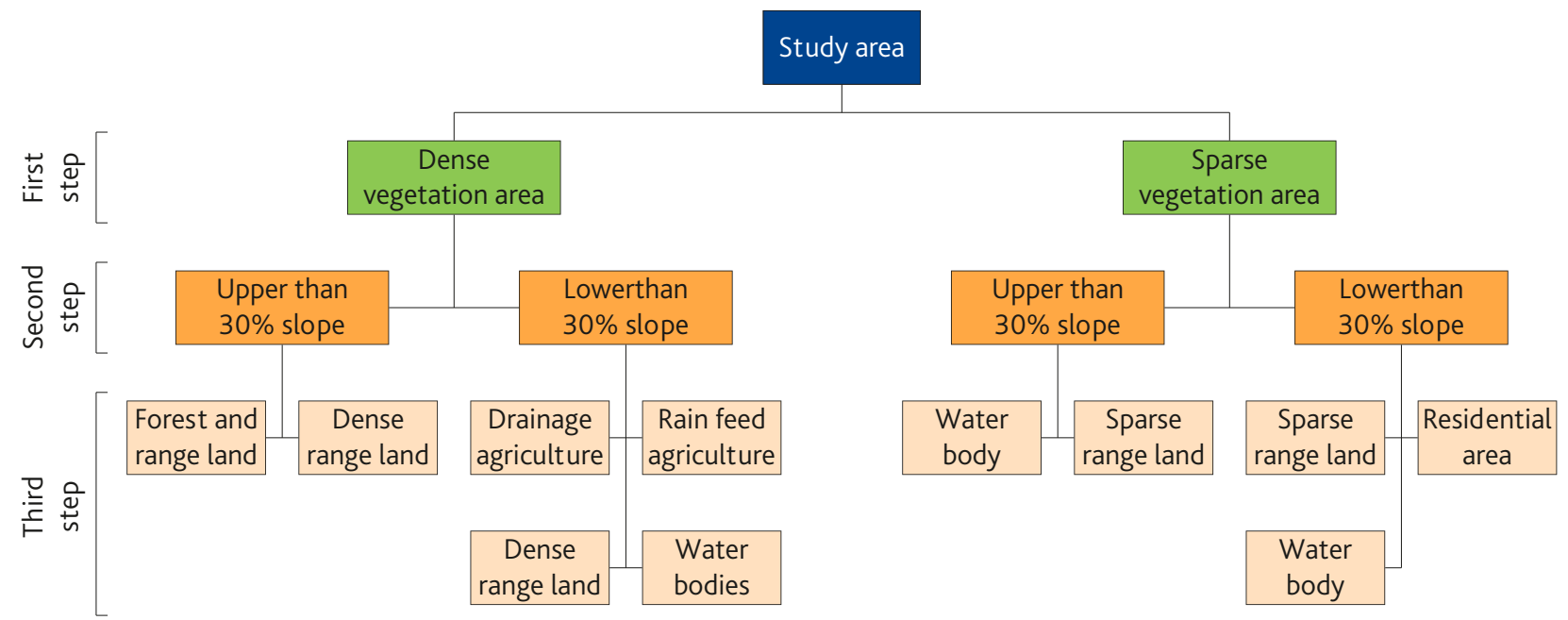

Figure2. Hierarchical structure of Pelasjan matrix

\section{First step}

At this step, the lower cover crown percentage of rainfed agriculture was considered as the threshold of 50\% cover crown for separating from sparse rangeland and other LULC. To map VCCP, NDVI index was used as follows (Equation 1) (Mukherjee, 2004; Oldeland et al., 2010; Peña \& Brenning, 2015):

$$
N D V I=\frac{N I R b-R E D b}{N I R b+R E D b}
$$

Simple linear regression was done between samples taken as the dependent variables and their NDVI values for each image as independent variables. Using prepared VCCP models, the VCCP maps prepared two classes of dense vegetation and sparse vegetation. Field control and comparison with FCC image showed that there were some mixings between the cultivation area (especially rain fed agriculture) and dense rangeland. In this step, because of drainage, agriculture areas separate more correctly.

\section{Second step}

For initial separation of the rain-fed agricultural area and dense rangeland during field studies, and by overlaying first step vegetation map on slope percentage image, it become clear that 30 percent slope was the threshold between rain-fed area and dense rangeland. On the other hand, there was no rain-fed cultivation over 30 percent slope in mountain areas. By applying 30 percent slope threshold in the first step, dense vegetation in more than 30 percent, which were mostly dense rangelands and forests, were separated from dense vegetation in less than 30 percent slope that were mostly drainage and rain-fed agricultural areas (Figure 2).

\section{Third level}

On the third level of the hierarchical model (Figure 2), four categories: drainage, rain-fed agriculture, forest and dense rangeland were considered as the sub-classes for the dense vegetation (>50\% vegetation coverage). On the other hand, three categories were determined as the sub-classes for the low-density vegetation $(<50 \%)$ including residential areas, sparse rangeland, and land under water. Because agriculture lands have geomatics shapes, by paying attention to their reflectance and their shape, they were classified as rain-fed and drainage agriculture using object-based image classification method, and were separated from satellite data. Other LULCs were classified with Fisher supervised image classification. Residential area maps for TM image were produced using TM image for January1998 when the land was totally covered with snow, only residential areas did not have snow cover; and residential areas were separated by applying Fisher image classification method.

Finally, all the individual layers were combined to produce LULCs maps.

\section{Maps accuracy assessment}

For accuracy assessment, samples were collected in field studies and were used for TM images. Some areas were selected as samples by considering field studies results and FCC images comparison. The overall accuracy and Kappa coefficient, commission error and omission were also determined. 


\section{Results and discussion}

\section{Satellite image classification}

In supervised classification methods, especially in Fisher classification method, to produce accurate maps, it is important to take samples that are really pure samples of each land-use reflectance (Al-doski et al., 2013). Therefore, samples for each land-use must be prepared in areas far from margins of a land-use/ land-cover. In this study, by proposing a sampling in heterogeneous area of each land-use/land-cover and by taking at least 30 meters distance from marginal land-use/land-cover (pixels in border of two land uses/land covers), we managed to achieve pure samples that were really samples of a land use/land-cover (LULC).

Image classifications results have shown that LULC classes with similar reflectance values in different bands have more errors. Moreover, small patches of isolated land covers can increase the classification errors because of impacts of the reflections from the adjacent pixels. In their studies, Luna, Cesar (2003); Yuan et al.(2005); Kamusoko and Aniya (2007); Lakshmi et al. (2015); Estoque and Murayama (2015), mentioned that similarity between LULCs increase errors in image classification. Kamusoko and Aniya (2007) explained that the accuracy of the classification depends on the degree of differentiation among the spectral reflections of LULC classes. Figures $3 a$ and $3 b$ show graphs signatures over used bands for TM and OLI simultaneously either as a spectral response pattern or mean reflectance $\left(b_{1 \ldots n}=\right.$ band number).

As shown in figures $3 \mathrm{a}$ and $3 \mathrm{~b}$, especially the dense rangeland and rain-fed agriculture follow almost similar reflectance patterns in all bands of the imageri(d). In these images, rain-fed, dense rangeland and forest almost have the same reflectance trend. Residential areas have high reflectance in all bands, and water reflectance is the lowest after near infrared band.

In this study, by paying attention to LULC similarity and complexity, hierarchical scheme of LULC was designed for satellite image classification. Disperati et al. (2015), for satellite image classification, designed 3 and 4 levels for land classes and mentioned they produced land maps in each level; and at the end, they combined all results together to achieve the final LULC map.

In this study, for VCCP, models were prepared using NDVI index that is a common and useful vegetation index for surviving different kinds of plants (Mukherjee, 2004; Oldeland et al., 2010; Jovanović et al., 2015). Formulae 2 and 3 have shown the vegetation cover crown percentage model.

Equivalent 2:

$\mathrm{Y}=179.3 \mathrm{X}+24.89$

$\mathrm{R}^{2}=0.89 \mathrm{P}$-value $<0.01$ for the year 2016
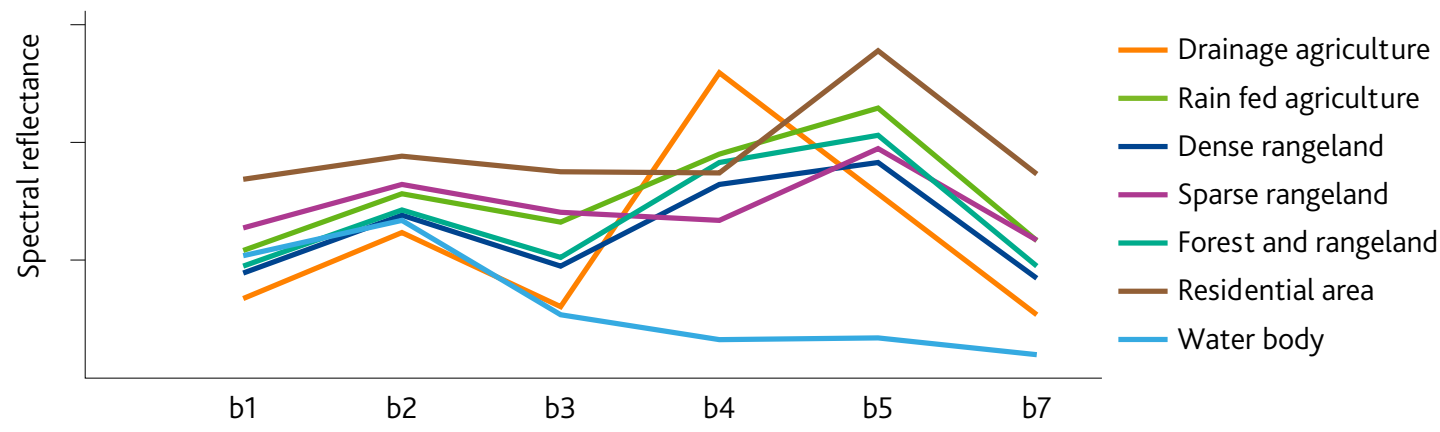

Figure 3a. An example of the spectral profile for TM

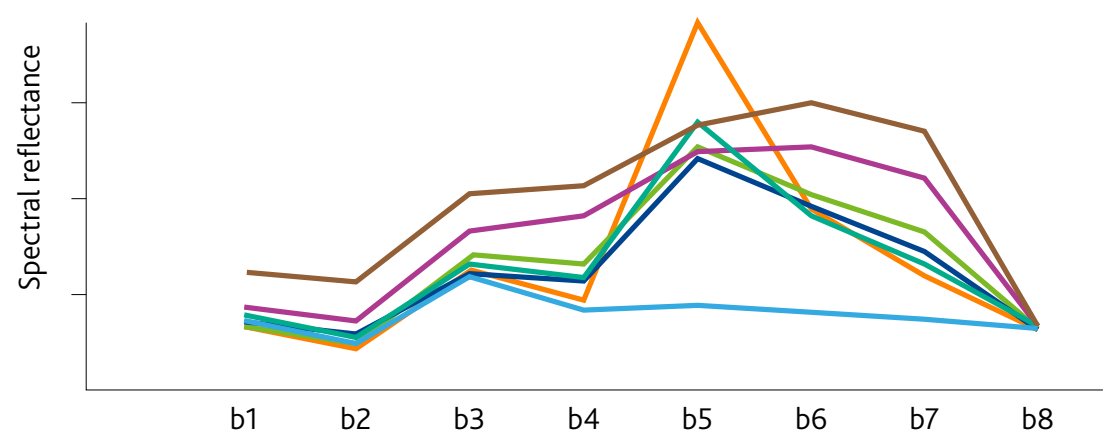

_ Drainage agriculture

— Rain fed agriculture

- Dense rangeland

— Sparse rangeland

- Forest and rangeland

— Residential area

Water body

Figure 3b. An example of the spectral profile for OLI 


\section{Equivalent 3:}

$\mathrm{Y}=240.95 \mathrm{X}+16.13$

$\mathrm{R}^{2}=0.80$ P-value $<0.0$ for the year 1998

Where $\mathrm{Y}$ is vegetation cover crown percentage, and $\mathrm{X}$ is values in NDVI index.

The range of NDVI values are -1 to 1 , the lower values show lower VCCP and the upper values are related to areas with more VCCP. In this study, initial image classifications showed that it was not possible to separate agricultural area especially rain-fed agriculture from dense rangeland. In addition, NDVI classification on the basis of produced modes could not separate dense rangeland from agriculture areas in the first level. The field samplings and overlaying FCC images on slope map indicated that dense rangelands are normally located on slopes greater than 30 percent in mountain areas, while drainage and rain-fed agriculture were located on slopes less than 30 percent slope. Thus, by overlaying the slope layer on the satellite images in GIS area using multiple method, dense rangelands which were mostly located on mountain areas were separated.

Finally, LULC maps were proposed using the conceptual model, and images were classified with hybrid method in 7 layers for years 1998 and 2016. Yuan, et al. (2005); Kamusoko and Aniya (2007) used hybrid image classification and explained that this method is applicable in land with complex reflectance. Figures $4 \mathrm{a}$ and $\mathrm{b}$ and $5 \mathrm{a}$ and $\mathrm{b}$, respectively show LULC maps of the area in the second and third stages. Table 4 shows each class area in hectares.

Residential areas that were small patches were distributed across the study area, and therefore their reflectance was influenced by the neighboring pixels (Malmir et al., 2015). Fisher classification method was able to separate the residential areas in both sensors. In some cases, residential areas and low-density rangeland were classified as one class in TM sensor images. Fisher supervised classification method can separate LULC with high accuracy when training sites were collected accurately (Al-doski et al., 2013). In this study, samples from each LULC were collected by paying attention to OLI spatial resolution; and they were collected in homogenous areas. Table 4 shows there is no significant change in drainage agriculture area and increase in rain-fed agriculture. From 1998 to 2016, water area in The Zayandehrood dam had a 1671-hectare decrease. On the basis of table 2, during this time, dense rangelands and forests decreased, too.

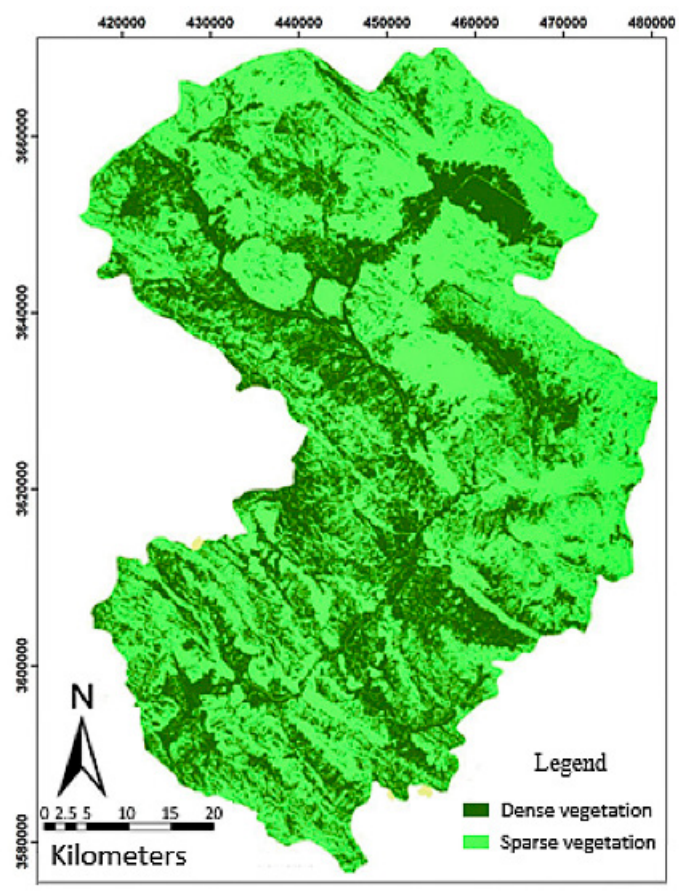

Figure.4a. Dense and sparse vegetation (level 2)

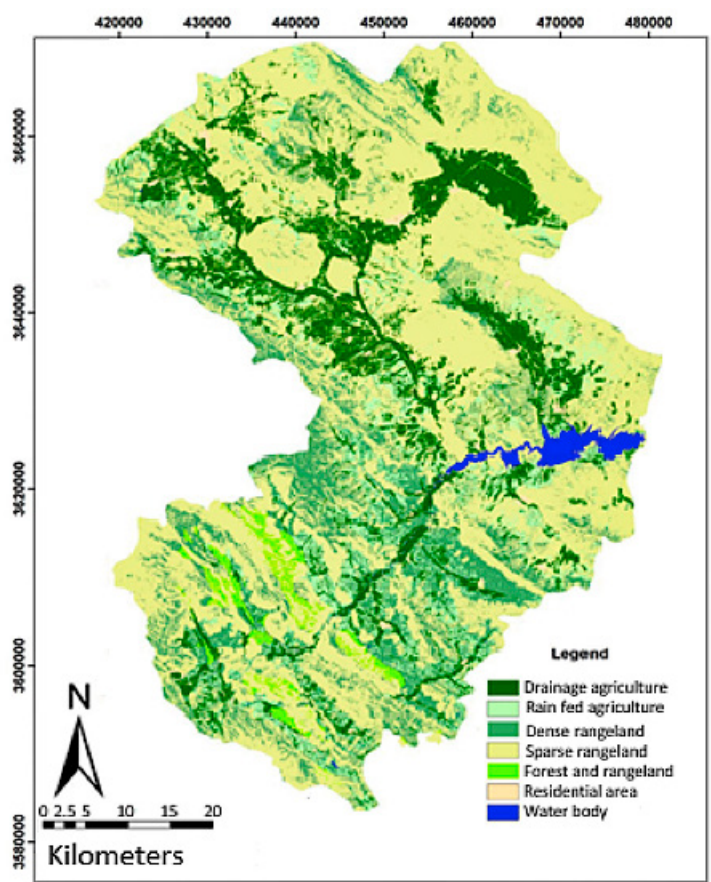

Figure.4b. LULC map (level 3)

Table 4. Pelasjan sub-basin LULC area (Hectare)

\begin{tabular}{|l|c|c|c|c|c|c|c|}
\hline $\begin{array}{l}\text { LULC class/ } \\
\text { Area (ha) }\end{array}$ & $\begin{array}{c}\text { Drainage } \\
\text { agriculture }\end{array}$ & $\begin{array}{c}\text { Rain-fed } \\
\text { agriculture }\end{array}$ & $\begin{array}{c}\text { Dense } \\
\text { range land }\end{array}$ & $\begin{array}{c}\text { Sparse } \\
\text { range land }\end{array}$ & Forest & $\begin{array}{c}\text { Residential } \\
\text { area }\end{array}$ & $\begin{array}{c}\text { Water } \\
\text { body }\end{array}$ \\
\hline Class area 1998 & 58665 & 18285 & 58135 & 257929 & 12028 & 3467 & 4490 \\
\hline Class area 2016 & 58029 & 25685 & 48854 & 262406 & 11102 & 4269 & 2654 \\
\hline
\end{tabular}




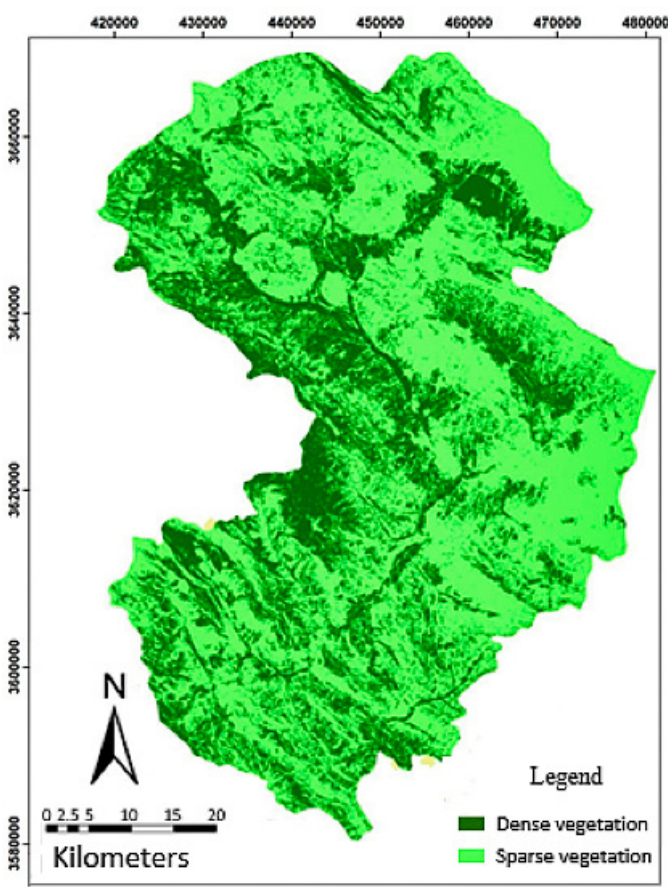

Figure 5a. Dense and sparse vegetation 5(level 2)

\section{Accuracy assessment of classification}

In this study, for classification accuracy assessment using field study samples and produced maps, error matrices produced for hybrid method results, and kappa coefficient, overall accuracy, precision of producer and user, commission and omission errors were

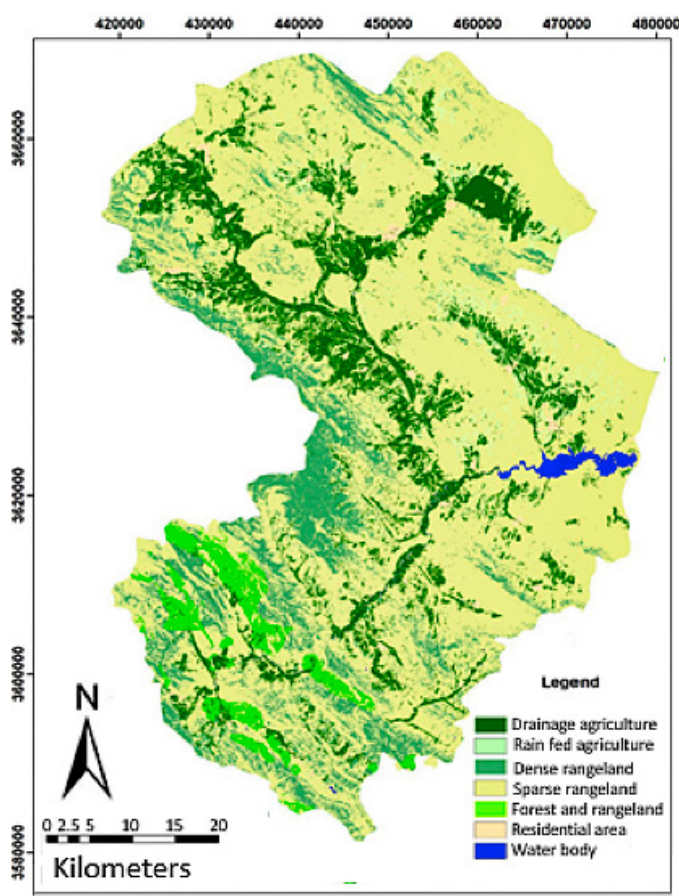

Figure 5b. 9LULC map (level 3)

calculated and shown in Tables 5 and 6 (Lunetta \& Lyon, 2004; Benfield et al., 2007; Al-doski et al., 2015, Lakshmi et al., 2015).

Error matrices, tables 5 and 6, show that most errors related to misclassified areas are related to rainfed and drainage agriculture areas and dense range

Table 5. LULC error matrix for map1998 (Pixel)

\begin{tabular}{|l|c|c|c|c|c|c|c|c|c|}
\hline Classes & $\begin{array}{c}\text { Drainage } \\
\text { agriculture }\end{array}$ & $\begin{array}{c}\text { Rain-fed } \\
\text { agriculture }\end{array}$ & $\begin{array}{c}\text { Dense } \\
\text { range } \\
\text { land }\end{array}$ & $\begin{array}{c}\text { Sparse } \\
\text { range } \\
\text { land }\end{array}$ & Forest & $\begin{array}{c}\text { Residential } \\
\text { area }\end{array}$ & $\begin{array}{c}\text { Water } \\
\text { body }\end{array}$ & Total & ErrorC \\
\hline $\begin{array}{l}\text { Drainage } \\
\text { agriculture }\end{array}$ & 21695 & 448 & 1825 & 21 & 857 & 164 & 0 & 25037 & 0.1335 \\
\hline $\begin{array}{l}\text { Rain-fed } \\
\text { agriculture }\end{array}$ & 1850 & 3017 & 1850 & 511 & 627 & 13 & 0 & 6069 & 0.5017 \\
\hline $\begin{array}{l}\text { Dense } \\
\text { range land }\end{array}$ & 166 & 539 & 24564 & 2114 & 1947 & 1 & 0 & 29331 & 0.1625 \\
\hline $\begin{array}{l}\text { Sparse } \\
\text { range land }\end{array}$ & 408 & 209 & 1772 & 42715 & 3721 & 550 & 0 & 49375 & 0.1351 \\
\hline Forest & 0 & 0 & 1660 & 454 & 6973 & 0 & 0 & 7887 & 0.1159 \\
\hline $\begin{array}{l}\text { Residential } \\
\text { area }\end{array}$ & 63 & 0 & 0 & 425 & 0 & 3636 & 0 & 3944 & 0.1021 \\
\hline $\begin{array}{l}\text { Water } \\
\text { body }\end{array}$ & 0 & 0 & 0 & 0 & 0 & 0 & 14552 & 14552 & 0 \\
\hline Total & 24119 & 4213 & 31671 & 46240 & 14125 & 4681 & 14552 & 136195 & - \\
\hline Error0 & 0.1028 & 0.2839 & 0.2244 & 0.0762 & 0.5063 & 0.2232 & 0 & - & - \\
\hline
\end{tabular}

ErrorO $=$ Errors of Omission (expressed as proportions)

Error $C=$ Errors of Commission (expressed as proportions)

90\% Confidence Interval $=+/-0.000815(0.046447-0.048076)$

$95 \%$ Confidence Interval $=+/-0.000971(0.046291-0.048232)$

$99 \%$ Confidence Interval $=+/-0.001278(0.045984-0.048539)$

Kappa: 0.81

Overall accuracy: 0.84 
Table 6. LULC error matrix for map 2016 (Pixel)

\begin{tabular}{|l|c|c|c|c|c|c|c|c|c|}
\hline & $\begin{array}{c}\text { Drainage } \\
\text { agriculture }\end{array}$ & $\begin{array}{c}\text { Rain-fed } \\
\text { agriculture }\end{array}$ & $\begin{array}{c}\text { Dense } \\
\text { range } \\
\text { land }\end{array}$ & $\begin{array}{c}\text { Sparse } \\
\text { range } \\
\text { land }\end{array}$ & Forest & $\begin{array}{c}\text { Residential } \\
\text { area }\end{array}$ & $\begin{array}{c}\text { Water } \\
\text { body }\end{array}$ & Total & ErrorC \\
\hline $\begin{array}{l}\text { Drainage } \\
\text { agriculture }\end{array}$ & 23608 & 998 & 463 & 106 & 93 & 95 & 0 & 25363 & 0.0692 \\
\hline $\begin{array}{l}\text { Rain-fed } \\
\text { agriculture }\end{array}$ & 537 & 5240 & 1665 & 23 & 19 & 5 & 0 & 7489 & 0.3003 \\
\hline $\begin{array}{l}\text { Dense range } \\
\text { land }\end{array}$ & 15 & 1047 & 28549 & 71 & 1019 & 0 & 0 & 29669 & 0.0700 \\
\hline $\begin{array}{l}\text { Sparse range } \\
\text { land }\end{array}$ & 573 & 15 & 2758 & 43088 & 1336 & 181 & 0 & 48983 & 0.1203 \\
\hline Forest & 0 & 0 & 1784 & 0 & 13241 & 0 & 0 & 15025 & 0.1187 \\
\hline $\begin{array}{l}\text { Residential } \\
\text { area }\end{array}$ & 0 & 0 & 0 & 264 & 99 & 3390 & 0 & 3753 & 0.0967 \\
\hline Water body & 0 & 0 & 0 & 0 & 0 & 0 & 14552 & 14552 & 0 \\
\hline Total & 24733 & 7300 & 33577 & 45594 & 15907 & 3171 & 14552 & 144834 & - \\
\hline Error0 & 0.0454 & 0.2821 & 0.1893 & 0.0106 & 0.1623 & 0.0765 & 0 & 131668 & - \\
\hline
\end{tabular}

ErrorO = Errors of Omission (expressed as proportions)

ErrorC $=$ Errors of Commission (expressed as proportions)

90\% Confidence Interval $=+/-0.000815(0.046447-0.048076)$

$95 \%$ Confidence Interval $=+/-0.000971(0.046291-0.048232)$

$99 \%$ Confidence Interval $=+/-0.001278(0.045984-0.048539)$

Kappa: 0.87

Overall accuracy: 0.91

lands together. Figures 3.a and b show that these misclassifications are related to similarity between drainage and rain-fed agriculture in dense rangeland areas. TM error matrix (table 5) has shown that most misclassifications are for relating rain-fed agriculture to dense rangelands and forests.

Table 6indicates that in the map prepared by OLI image, rain-fed agriculture, drainage agriculture, dense and sparse rangelands were separated correctly. In prepared maps, some drainage agricultural pixels are wrongly related to residential areas because of small green spaces in residential areas. On the other hand, because forests included trees and rangeland to- gether, in this class, there is a high misclassification between different vegetation classes, and therefore it has high commission and omission error in two imageries.

Using TM and OLI images, land-use/land-cover was extracted due to different reflectance behaviors of water compared to other phenomena (Figure $3 \mathrm{a}$ and $\mathrm{b}$ ). Tables 5 and 6 show produced map using TM sensor has overall accuracy $84 \%$ and with kappa coefficient 0.81 , and produced map using OLI sensor has overall accuracy $91 \%$ and with kappa coefficient 0.87 ,which is more than TM. This difference was predictable because of OLI characteristics like more radiometric and spectral resolution.

\section{Conclusion}

LULC spectral profiles have shown LULCs digital numbers were more separated in OLI with 16-bit than TM data, so this is the reason for the less accuracy in TM map with 8-bit radiometric resolution (Figures 3a and $3 \mathrm{~b}$ ). Applying proposed hybrid method inland hierarchy concept could produce almost the same accurate maps for two imageries data. In this study, Fisher classification (Al-doski et al., 2013), object-based classification (Blaschke, 2010; Vieira et al., 2012; Phinn et al., 2012), and NDVI vegetation index (Peña \& Brenning, 2015; Oldeland et al., 2010) were used in designed hybrid classification method.
Error matrices have shown more accurate image classification results in the map provided by OLI sensor than TM, especially in mapping different vegetation types and separating land surfaces such as residential areas.

Considering the similarity of some LULC reflectance in this study, in the hierarchy concept of land matrix, hybrid method can produce acceptable LULC maps. Thus, providing detailed maps of LULC that have small areas and similar reflectance will be possible through appropriate methods for each defined land level using different imageries. 


\section{References}

Al-doski, J., Shattri, M., \& Zulhaidi, M.S. (2013). Image classification in remote sensing. Journal of Environment and Earth Science, 3(10), 141-147.

Anderson, J.R. (1976). A Land Use and Land Cover Classification System for Use with Remote Sensor Data. U. S. Government Printing Office.

Benfield, S.L., Guzman, H.M., Mair, J.M., \& Young, J.A.T. (2007). Mapping the distribution of coral reefs and associated sublittoral habitats in Pacific Panama: a comparison of optical satellite sensors and classification methodologies. International Journal of Remote Sensing, 28, 5047-5070.

Blaschke, T. (2010). Object based image analysis for remote sensing. ISPRS Journal of Photogrammetry and Remote Sensing, 65, 2-16.

Chrysoulakis, N., Abrams, M., Feidas, H., \& Korei, A. (2010). Comparison of methods using ASTER data for the area of Crete, Greece. International Journal of Remote Sensing, 31(24), 6347-6385.

Di Gregorio, A. (2005). Di Gregorio, A. (2005). Land cover classification system: Classification concepts and user manual: LCCS (No. 8). Rome: Food and Agriculture Organization of the United Nations.

Disperati, L., Gonario, S., \& Virdis, P. (2015). Assessment of land-use and land-cover changes from 1965 to 2014 in Tam Giang-Cau Hai Lagoon, central Vietnam. Applied Geography, 58, 48-64.

Estoque, R.C., \& Murayama, Y. (2015). Classification and change detection of built-up lands from Landsat-7 ETM+ and Landsat-8 OLI/TIRS imageries: A comparative assessment of various spectral indices. Ecological Indicators journal, 56, 205-217.

Feranec, J., Hazeu, G., Christensen, S., \& Jaffrain, G. (2007). CORINE land cover change detection in Europe (case studies of the Netherlands and Slovakia). Land Use Policy, 24(1), 234-247.

Feranec, J., Jaffrain, G., Soukup, T., \& Hazeu, G. (2010). Determining changes and flows in European landscapes $1990 e 2000$ using Corine land cover data. Applied Geography, 30(1), 19-35.

Gao, J., \& Xu, L. (2016). An efficient method to solve the classification problem for remote sensing image. AEU - International Journal of Electronics and Communications, 69(1), 198-205.

Homer, C., Huang, C., Yang, L., Wylie, B., \& Coan, M. (2004). Development of a 2001 national land cover database for the United States. Photogrammetric Engineering and Remote Sensing, 70(7), 829-840.

Jia, K., Wei, X., Gu, X., Yao, Y., Xie, X., \& Li, B. (2014). Land cover classification using land sat 8 operation land imager data in Beijing, China. Geocarto international, 29(8), 941-951.
Jovanović, M., \& Milanović, M. (2015). Normalized Difference Vegetation Index (NDVI) as the Basis for Local Forest Management. Example of the $\mathrm{Mu}$ nicipality of Topola, Serbia. Polish Journal of Environmental Studies, 24(2), 529-535.

Julien, Y., Sobrino, J.A., \& Jiménez-Muñoz, (2011). Land use classification from multi-temporal Landsat imagery using the Yearly Land Cover Dynamics (YLCD) method. International Journal of Applied Earth Observation and Geoinformation, 13, 711-720.

Kamusoko, C., \& Aniya, M. (2007). Land use/cover change and landscape fragmentation analysis in the Bindura District, Zimbabwe. Land Degradation and Development, 18(2), 221-233.

Knudby, A., Mtwana, N.L., Palmqvistc, G., Wikströmc, K., Koliji, A., Lindborgd, R., \& Gullströmc, M. (2014). Using multiple Landsat scenes in an ensemble classifier reduces classification error in a stable nearshore environment. International Journal of Applied Earth Observation and Geo-information, 28, 90-101.

Lakshmi, N., Kantakumar, L.N., \& Neelamsetti, P. (2015). Multi-temporal land use classification using hybrid approach. The Egyptian Journal of Remote Sensing and Space Sciences, 18(2), 289-295.

Luna, A.R., \& Cesar, A.R. (2003). Land use, land cover changes and costal lagoon surface reduction associated with urban growth in northwest Mexico. Landscape Ecology, 18(2), 159-171.

Lunetta, R.S., \& Lyon, J.G. (2004). Remote Sensing and GIS Accuracy Assessment. CRC Press.

Malmir, M., Kheirkhah, Z.M.M., Monavari, S.M., Jozi, S.A., \& Sharifi, S. (2015). Urban development change detection based on Multi-Temporal Satellite Images as a fast tracking approach-a case study of Ahwaz County, southwestern Iran. Environmental monitoring and assessment, 187(3), 108.

Mei, A., Ciro, M., Fontinovo, M., Bassani, A.A., \& Petracchini, F. (2015). Landsat 8 vs. Landsat 5: A comparison based on urban and peri-urban land cover mapping Dimitris.. Journal of African earth science, 5, 15-24.

Misra, A., \& Balaji, R. (2015). A Study on the Shoreline Changes and LAND-use/ Land-cover along the South Gujarat Coastline. Procedia Engineering, 116, 381-389. doi:10.1016/j.proeng.2015.08.311

Mukherjee, S. (2004). Text Book of Environmental Remote Sensing. New Delhi: Macmillan India Limited. Nurdin, N., Komatsu, T., Agus, , Akbar, A.M., Djalil, A.R., \& Amri, K. (2015). Multisensor and multitemporal data from Landsat images to detect damage to coral reefs, small islands in the Spermonde ar- 
chipelago, Indonesia. Ocean Science Journal, 50(2), 317-325. doi:10.1007/s12601-015-0029-x

Oldeland, J., Dorigo, W., Lieckfeld, L., Lucieer, A., \& Jürgens, N. (2010). Combining vegetation indices, constrained ordination and fuzzy classification for mapping semi-natural vegetation units from hyperspectral imagery. Remote Sensing of Environment, 114(6), 1155-1166. doi:10.1016/j.rse.2010.01.003

Peña, M.A., \& Brenning, A. (2015). Assessing fruittree crop classification from Landsat-8 time series for the Maipo Valley, Chile. Remote Sensing of Environment, 171, 234-244. doi:10.1016/j.rse.2015.10.029

Phinn, S.R., Roelfsema, C.M., \& Mumby, P.J. (2012). Multi-scale, object-based image analysis for mapping geomorphic and ecological zones on coral reefs. International Journal of Remote Sensing, 33(12), 3768-3797. doi:10.1080/01431161.2011.6331 22

Poursanidis, D., Chrysoulakis, N., \& Mitraka, Z. (2015). Landsat 8 vs. Landsat 5: A comparison based on urban and peri-urban land cover mapping. International Journal of Applied Earth Observation and Geoinformation, 35, 259-269. doi:10.1016/j. jag.2014.09.010

Purkis, S., \& Klemas, V. (2011). Remote Sensing and Global Environmental Change. West Sussex, UK: Wiley-Blackwell. doi:10.1002/9781118687659

Purkis, S.J., Myint, S.W., \& Riegl, B.M. (2006). Enhanced detection of the coral Acropora cervicornis from satellite imagery using a textural oper- ator. Remote Sensing of Environment, 101(1), 82-94. doi:10.1016/j.rse.2005.11.009

Roy, D.P., Wulder, M.A., Loveland, T.R., C.E. Woodcock, , Allen, R.G., Anderson, M.C., . . . Bindschadler, R. (2014). Landsat-8: Science and product vision for terrestrial global change research. Remote Sensing of Environment, 145, 154-172. doi:10.1016/j. rse.2014.02.001

Stenzel, S., Fassnacht, F.E., Mack, B., \& Schmidtlein, S. (2017). Identification of high nature value grassland with remote sensing and minimal field data. Ecological Indicators, 74, 28-38. doi:10.1016/j. ecolind.2016.11.005

Tian, B., Zhou, Y., Thom, R.M., Diefenderfer, H.L., \& Yuan, Q. (2015). Detecting wetland changes in Shanghai, China using FORMOSAT and Landsat TM imagery. Journal of Hydrology, 529, 1-10. doi:10.1016/j.jhydrol.2015.07.007

Vieira, M.A., Formaggio, A.R., Rennó, C.D., Atzberger, C., Aguiar, D.A., \& Mello, M.P. (2012). Object Based Image Analysis and Data Mining applied to a remotely sensed Landsat time-series to map sugarcane over large areas. Remote Sensing of Environment, 123, 553-562. doi:10.1016/j.rse.2012.04.011

Yuan, F., Sawaya, K.E., Loeffelholz, B.C., \& Bauer, M.E. (2005). Land cover classification and change analysis of the Twin Cities (Minnesota) Metropolitan Area by multitemporal Landsat remote sensing. Remote Sensing of Environment, 98(2-3), 317328. doi:10.1016/j.rse.2005.08.006 